\title{
Fieldwork in Ground Zero, Mallorca. A Methodological Fieldwork Proposal for a Geographical Analysis of Tourist Areas
}

\author{
Trabajo de campo en la Zona Cero, Mallorca. \\ Propuesta metodológica de análisis geográfico de núcleos turísticos
}

\author{
Macià Blázquez-Salom ${ }^{1^{*}}$ (1) \\ Asunción Blanco-Romero² (D)
}

\begin{abstract}
For scientific headway to be made in the field of social science today, direct contact with analysed phenomena is all-important. The research hypothesis we put forward is that, just like practical laboratory work, fieldwork is an indispensable tool in tourism geography in guaranteeing rigorous scientific studies. The aim of this paper is: 1) to help demonstrate the usefulness of fieldwork in tourism geography in enriching the taught theory and concepts; 2) to design useful methodological tools for planning studentdriven, enquiry-based learning processes; 3 ) to use Mallorca as a case study in a direct analysis of the complex spatial consequences of the Anthropocene on the tourist industry. Our teaching and research experience in tourism geography, particularly in relation to global change during the Anthropocene, are fundamental in achieving these objectives. We conclude that fieldwork helps students to develop important skills and competences, facilitating meaningful learning. Through the students' active participation, the teacher is no longer a transmitter of theoretical knowledge, but a facilitator in the learning process.
\end{abstract}

Keywords: tourism geography; Mallorca; fieldwork; Anthropocene; meaningful learning; experimentation; skills and competences.

\section{Resumen}

La importancia para el avance científico del contacto directo con los fenómenos analizados es actualmente incuestionable en las ciencias sociales. De manera similar a la investigación de laboratorio, nuestra hipótesis defiende que el trabajo de campo en geografía del turismo es una herramienta insoslayable para llevar a cabo un estudio científico riguroso. En este contexto, el presente estudio propone: 1) contribuir a demostrar la utilidad del trabajo de campo para enriquecer el proceso de aprendizaje de geografía del turismo, mediante la definición de su corpus conceptual y teórico; 2) diseñar herramientas metodológicas útiles para planificar procesos de aprendizaje basados en la autonomía de los estudiantes y su enfoque basado en la indagación; 3) usar el caso de Mallorca para ejemplificar su aplicabilidad al análisis de las complejas consecuencias territoriales del Antropoceno en la industria turística. Para alcanzar estos objetivos, se utiliza la experiencia directa de enseñanza e investigación en geografía del turismo y, en particular, sus vínculos con el Antropoceno. Concluimos que el trabajo de campo ayuda a desarrollar habilidades y competencias importantes de los estudiantes, facilitando un aprendizaje significativo. La inscripción participativa del estudiante hace que el/la docente ya no sea un mero transmisor de conocimiento teórico, sino el facilitador en el proceso de aprendizaje.

Palabras clave: geografía del turismo; Mallorca; trabajo de campo; Antropoceno; aprendizaje significativo; experimentalidad; habilidades y competencias.

1 Geography Department. Universitat de les Illes Balears (Spain).mblazquez@uib.cat. * Corresponding author

2 Geography Department. Universitat Autònoma de Barcelona (Spain). asuncion.blanco@uab.cat 


\section{Introduction}

Direct contact with analysed phenomena is fundamentally important in science advancement. Fieldwork contributes to the acquisition of skills, tools and conducive attitudes to global change, just as practical laboratory work contributes to countless research processes. In an age of social isolation fostered by our dependence on ICTs, fieldwork is an innovative educational tool.

Planning teaching activities is always a creative challenge for teaching staff. In the current scenario of the COVID-19 pandemic, we long to take advantage of the benefits of fieldwork. With the resulting economic crisis, fieldwork will be needed in order to study spatial restructuring processes. At the same time, the health crisis will lead to a change in the tourism model. Based on these premises, one important challenge in social science education is to analyse the links between global change (including pandemics) and tourism. When tourism geography is taught in relation to contexts of global change, fieldwork can be an important means of intercultural enrichment (just as tourism can be) through interaction with others who are culturally different from us and by boosting a raised socio-ecological awareness, emotional intelligence, capacity for critical thinking and global citizenship.

The current crisis-driven world scenario points to situations of social polarization, particularly at mass tourist destinations. The COVID-19 pandemic has accentuated existing situations of polarized uneven geographical development, including ones relating to the tourist industry. Crises call for restructuring processes, and tourist destinations are not exempt from this (Murray, Yrigoy \& Blázquez-Salom, 2017). Mallorca is a Ground Zero in terms of its poor economic prospects, given the virtual halt in tourist flows caused by the pandemic (Bohórquez, 28/04/2020). Due to Mallorca's hyper-specialization in tourism, the Balearic government estimates that the archipelago will experience a 31\% drop in the GDP and the destruction of 147,000 jobs (Comunidad Autónoma de las Islas Baleares, [CAIB], 2020). Within the framework of global change during the Anthropocene, research into crisis processes caused by the COVID-19 pandemic raises numerous geographical issues that can be explored through fieldwork, in particular, the spatiality of social, economic and environmental change. At a more in-depth level, the issues to investigate include how economic crises have been used to restructure tourism; how tourists at destinations are segregated by social class and origin; what role domestic tourism can play in the recovery; how financial stimuli can mitigate climate change; and whether this is an opportunity to curb urban tourism growth, reshaping the built environment so that it is better adapted to scenarios of global change (Gössling, Scott, \& Hall, 2020) in terms of factors like transport infrastructure, accommodation capacities or shoreline and beach management.

\subsection{Aims and scope}

Within the above framework, this research paper aspires to design an approach to fieldwork for tourism geography students that focuses specifically on popular tourist resorts and their need for restructuring, given uncertain future scenarios of global change brought about during the Anthropocene. To study this issue, possible indicators relating to the following processes can be used: tourist and migratory mobility; increasing consumption of petroleum products for tourist transport; global warming; rising sea levels and their impact on beach management; changes in land use in built environments, such as urban sprawl or proposed extensions to airports; and the role of urban and regional planning. Further aims are: 1) to demonstrate the usefulness of fieldwork in enriching how the theoretical and conceptual rudiments of tourism geography are taught; 2) to design a set of methodological tools able to enrich the epistemology of fieldwork when used for teaching purposes; 3) to use a case study for the direct observation and analysis of the spatial consequences of the aforementioned processes. In this way, we intend to fill an existing gap by creating methodological guidelines for this kind of fieldwork.

With this as our premise, we set out to draw up detailed guidelines on how to use fieldwork in teaching and research activities, hence allowing students to gain a first-hand insight into certain phenomena and to compare geographic knowledge with realities. As a practical case study, we include an analysis of Mallorca: a unique testing ground offering multiple research opportunities. Our suggested topics for analysing the links between tourism and the Anthropocene are: 1) the interrelations among air traffic tourist flows, the consequences in terms of global warming and rising sea levels, and beach and seashore management; 2) land use changes in built environments, 3) planning the growth of tourist areas at an urban and regional level.

This paper is structured as follows. Chapter 2 reviews the state of the art, introducing some key concepts related to learning objectives (experimentation through fieldwork, and the purposes of geography 
and tourism geography). This is followed, in chapter 3, by a brief outline of the method used for our study. Chapter 4 describes the most common fieldwork tools and methods and our own methodological proposal, based on hypothesis development, data collection, observation, and mapping. Chapter 5 offers a proposed hypothetical-deductive guide, using Majorca as a case study, while chapter 6 outlines the strengths and weaknesses in relation to current knowledge on the subject, rounded off with some concluding remarks.

\subsection{State of the art}

In geography teaching, direct contact with reality, through fieldwork, can be used as a means of boosting skills and attitudes and acquiring useful tools. Fieldwork is based on the collection of primary data and it can take a real-world problem-solving approach, for instance, through Participatory Action Research methods (Breitbart, 2010). The COVID-19 pandemic has demonstrated the fragility of the mass tourism model and the need to prevent other global change catastrophes related to the Anthropocene (Crutzen, 2002), such as rising sea levels or growing inequality due to the uneven distribution of wealth. What the Anthropocene signifies is that the human impact on the world environment is now so large, within the Holocene's natural variability as a baseline for interpreting the world changes currently in progress, that the Earth has now entered a new geological epoch. As a concept, the Anthropocene automatically implies a connection with the physical world, linking humans-in our case students-to planet Earth and making humankind responsible for tackling these changes (Prince, 2020). Within this context and that of the tourist industry, one of the current era's most important challenges is for a specific response to be found to demands for appropriate, fair degrowth at most hitherto over-saturated coastal mass tourist destinations by boosting their socio-spatial resilience (Blanco-Romero \& Blázquez-Salom, 2021).

Geographical fieldwork is a connective practice (Haigh, 2017) that allows for the creation of an empathic, emotional relationship between the learner and an "other" (Monk, 2000). In an era of increasing social isolation, ICTs lead to spatio-temporal discontinuity -and what have been termed "deterritorialized spaces"-, where fragmented versions of reality are consumed (Antolín, 2019). Teaching through fieldwork can help to alleviate this disconnection from reality. In France and Haigh words: "Fieldwork is a signature pedagogy of geography. It is the place where geographers learn to connect classroom theory with the real world, where they learn to practice their geo-capabilities and key geographical skills as well as enhancing their general graduate capabilities, such as problem solving, critical thinking, team-working and emotional intelligence." (2018, p. 508).

This way, the challenge of fostering an interest in education by students can be overcome through real situations (Santiago, 1998). As a teaching strategy, fieldwork gives students the opportunity to experience natural phenomena through direct contact with them for the purposes of their scientific interpretation and analysis (Sánchez \& Godoy, 2002). This cognitive process can be described as meaningful learning; that is, feeling that all the components of a concept, idea, theory, formula, or argument come together. This process of meaningful learning occurs when students build up the knowledge and cognitive processes that are required to tackle problem-solving tasks (Torrisi-Steele, 2009).

Many other disciplines, like ecology, geology or anthropology, use fieldwork as a key strategy. For ethnographers, for instance, fieldwork does not have a structure that can be coded and taught. In other words, it is not a mysterious process: "There is nothing more to fieldwork than meets the naked eye" (Fletcher, 2007, p. 19). Individual reflection is all that is needed.

Fieldwork encourages experimentation, contributing to a better understanding and critical analysis of knowledge, much like the practical work conducted in laboratories, where, for instance, a particular phenomenon is reproduced and its response is determined when certain variables or independent controllable or explanatory factors are modified. In the field of social science, criteria are analysed and validated-for example, by studying documents or through reflection, discussion or the defence of roles-, attempting to reproduce realities in the classroom. Experimentation through fieldwork consists of an analysis of the variables that determine a non-reproducible social phenomenon. This implies studying the spatial realities of tourism and speculating on the explanations through a hypothetical-deductive exploratory analysis. Direct information gathered in the field provides first-hand data; that is, quantitative, qualitative or mixed samples that are hard to obtain through other remote analytical methods, such as aerial photography or satellite imagery. Last but not least, fieldwork contributes to an understanding of geographical phenomena through the development of techniques like observation, conjecture and explanation in the field. From a student viewpoint, fieldwork activities can be classified according to two basic criteria: observation (not 
interfering) versus participation (interacting, for instance making enquiries so as to gather answers to research questions), on the one hand, and dependency (listening to explanations, as in staff-led activities) versus autonomy (when students are in charge of the process) (Kent, Gilbertson \& Hunt, 1997). Within the scope of these possible options, participative observation and a certain degree of autonomy are an appropriate mix for problem-based learning (PBL) as a means of fostering self-experience and independent, critical learning processes through student-centred pedagogical tools (Pawson, et al., 2006; Thomas, 2009). France and Haigh (2018) offer a more detailed classification of types of fieldwork, summarised in Table 1.

Table 1. Types of fieldwork

\begin{tabular}{|c|c|}
\hline 1 & Teacher-centred, using fieldwork to illustrate the teacher's explanations, given during "Cook's Tour" coach stops. \\
\hline 2 & Fieldwork as a laboratory for surveying, mapping or sampling. \\
\hline 3 & Project-oriented, team-working and inquiry-based approaches which connect theory and practice. \\
\hline 4 & $\begin{array}{l}\text { Curriculum-centred to develop discipline-specific attributes, such as emotional intelligence, critical thinking, } \\
\text { problem solving and global citizenship. }\end{array}$ \\
\hline 5 & $\begin{array}{l}\text { Technologically-enhanced data collection and interactivity, exploiting the development of GIS, GPS, Google Earth, } \\
\text { Geotagging, Social Networking, etc. }\end{array}$ \\
\hline 6 & Research apprenticeship as hands-on experience of the processes of knowledge creation. \\
\hline 7 & $\begin{array}{l}\text { Reflective international fieldwork, as a means of contributing to the intercultural enrichment of the curriculum, } \\
\text { interacting with those who are not culturally akin to us (McMorran, 2015). }\end{array}$ \\
\hline
\end{tabular}

Source: France and Haigh (2018). Own design

In the field of geography, an initial body of literature was built up on fieldwork methods and its contributions, in particular by Piotr A. Kropotkin (1885), Elisée Reclus (1901) and Carl O. Sauer (1956). In a more radical approach to geography, William Bunge promoted "urban geographic expeditions" as an educational project involving the inhabitants of disadvantaged neighbourhoods in order to foster more democratic, participative teaching methods and activist forms of research (Benach, 2017). In geology, this technique was enriched by proposals like those of Pedrinaci, Sequeiros and García de la Torre (1994). Both disciplines have put forward solid arguments in favour of fieldwork methods, including Spanish defences by Manuel de Terán or Lluís Solé Sabarís, rooted in the pedagogical concept of geographical hikes, developed in Spain by the Institución Libre de Enseñanza (The Institute for Academic Freedom). Fieldwork was included in its learning activities, but not as part of the official curriculum. This consideration has only recently changed. A review of Spanish literature on the current use of fieldwork highlights four approaches: 1) as teaching resource; 2) in spatial interpretation; 3) for the presentation of case studies; and 4) incorporating ICTs (Morote, 2019). In tourism studies, fieldwork has mainly been used for case studies to explore and uphold the value of natural and cultural heritage (Mínguez, 2010) and, less often, to diagnose and offer solutions to the negative aspects of tourist development, such as the gentrification of urban public spaces due to tourism commodification (Martínez-Hernández and Yubero, 2020).

Through geography, spatial phenomena can be explained by examining interrelating social, economic and environmental variables, in addition to analysing the said variables' spatial distribution. Fieldwork thus combines direct data-gathering with the development of more comprehensive exploratory and explanatory geographical analysis techniques.

In recent times, tourism-an activity closely linked to new socio-economic dynamics-has brought about one of the biggest spatial changes in Spain (Murray, 2015), expanding to the point of overtourism and contributing to the Anthropocene's dynamics. Fieldwork-based geographical analyses of tourist areas offer a closer insight into real situations, and this is particularly important at times such as crisis points when sociospatial restructuring processes are needed (Murray et al., 2017). At a worldwide level, several solutions have been proposed to tackle problems associated with the Anthropocene like unequal geographical development, consumerism, and the accumulation of wealth. One of them is tourism degrowth in scenarios of overtourism. This is a socially-driven strategy as opposed to a situation of economic decline or recession. As Kallis et al. explain, "involuntary declines are not degrowth in themselves, and countries in recession or depression are not degrowth experiments" (2018, p. 294). Indeed, crises caused by things like natural disasters have nothing to do with degrowth, which should instead be seen as "radical political and economic reorganization leading to drastically reduced resource and energy throughput" (Kallis et al., 2018, p. 291). 
It is worth outlining the adaptation of methodologies and tools in order to tackle problems related to global change like the local population's loss of their everyday habitats due to climate change, the depletion of fossil fuels, a loss of biodiversity, and crossed biophysical resilience thresholds (BlancoRomero, 2019). The concept of resilience has aroused substantial interest among tourism researchers seeking ways of dealing with crises, disruptions and changes (Biggs, Hall \& Stoeckl, 2011). Socioecological approaches to spatial resilience have been addressed by various authors (Hopkins, 2010; Cork, 2009; Hudson, 2010; Wilding, 2011), with the establishment of new scenarios of social, economic and environmental stability (Walker, Holling \& Carpenter, 2004). Through this kind of socio-ecological approach, fundamental importance is lent to conservation, balanced ecosystems, and quality of life, while boosting the local community's participation in governance of the territory, as well as promoting equitable access to resources and services (Amat, 2013).

Our paper wishes to fill a gap in the use of fieldwork by taking advantage of field trips to analyse the links between tourism and global change. From a theoretical point of view, we intend to demonstrate the usefulness of fieldwork, contributing to epistemological recognition of its conceptual framework and using spatiality, a concept embedded in fieldwork learning, to reinforce the acquisition of skills, tools and conducive attitudes to global change. Our ultimate goal is to offer a series of theoretical considerations and a useful model for teachers and researchers. In theoretical terms, we agree with Büscher and Fletcher (2020) in their defence of a political ecology approach, centred on a critique of contemporary capitalism that can shift debate on the Anthropocene onto more realistic ground. Global change in the Anthropocene calls for alternative realistic approaches, based on-but not confined to-past experience; that is, rooted in tangible historical experience but also taking into account imaginative solutions (Wark, 2015). Because global catastrophes, like the COVID-19 pandemic, force us to acknowledge the fact that, even today, we still face high levels of social inequality, growing environmental degradation and economic stagnation, the search for post-growth, post-capitalist, post-development alternatives has become a social and intellectual imperative, for instance through genuine, fair degrowth (Fletcher, Murray, Blanco-Romero \& Blázquez-Salom, 2019). In addition to all the above, through the design of some experimental procedures to incorporate in fieldwork practices, we contribute to possible methodological advances.

\section{Methodology}

This paper aspires to help establish why and how fieldwork learning activities can be used to analyse the relationship between tourism and global change. To do this, a summarized review was made of the theory and practical application of fieldwork to tourism geography. First, we studied the underlying theoretical framework that supports its usefulness, particularly as a teaching tool in university studies and in analysing the links between tourism and global change during the Anthropocene. Second, methodological guidelines were drawn up to plan the use of field trips in teaching, based on scientific analytical methods. Finally, the applicability of fieldwork to analyses of tourist areas of Mallorca was illustrated.

Our hypothesis is that fieldwork is a particularly suitable tool for developing the following competences and skills in students, tying in the theory studied in the classroom with the real world (France \& Haigh, 2018): a) improved student autonomy in analysing realities, facilitating the acquisition of meaningful knowledge; b) a raised environmental awareness and desire to seek a solution to the global changes brought about by humankind during the Anthropocene; and c) an insight into reality through direct contact with it as a means of tackling current socio-ecological problems.

Furthermore, when fieldwork is used in teaching, students engage in problem solving and they boost their capacity for critical thinking (in keeping with France and Haigh, 2018), exploring how to address and manage the impacts of global change on coastal tourist destinations. We use examples of popular mass tourism resorts, detailing the activities and input to be worked on during the field trips. These proposed methodological ideas have been tested out many times during the last three decades with hundreds of undergraduate and postgraduate tourism, geography and teacher-training students, not just from Spanish universities but also from other European ones (Switzerland, Germany, the Netherlands, etc.). We take advantage of this experimental design to work on learning objectives transposable to other contexts, dealing with the links between tourism and global change. In addition, we propose a specific practical exercise aimed at analysing tourism's relationship with the global changes brought about during the Anthropocene; that is, the effects of rising sea levels due to global warming, changes in land use, and urban and tourism planning. 


\section{Results}

From reflections on teaching theory and practice, a series of general conclusions were reached on how fieldwork can contribute to the teaching of tourism geography within the framework of the Anthropocene, focusing on: 1) how to adapt hypothetical-deductive procedures to fieldwork planning methods; 2) the organization of fieldwork activities; and 3) the role of the teacher and students in the implementation of activities.

A practical example of the proposed methodology is given in section 5 .

\subsection{The characteristics of fieldwork and its usefulness}

For fieldwork to be used as a means of understanding and analysing certain realities, some preliminary steps and guidelines are needed. In the planning of learning activities to back up theory (e.g. tourism geography lectures) and in academic research (such as final or master's degree projects or doctoral theses), a method must first be established, defining the main premises, sources of information and dataprocessing procedures (see Figure 1).

Figure 1. Main steps in the proposed fieldwork method

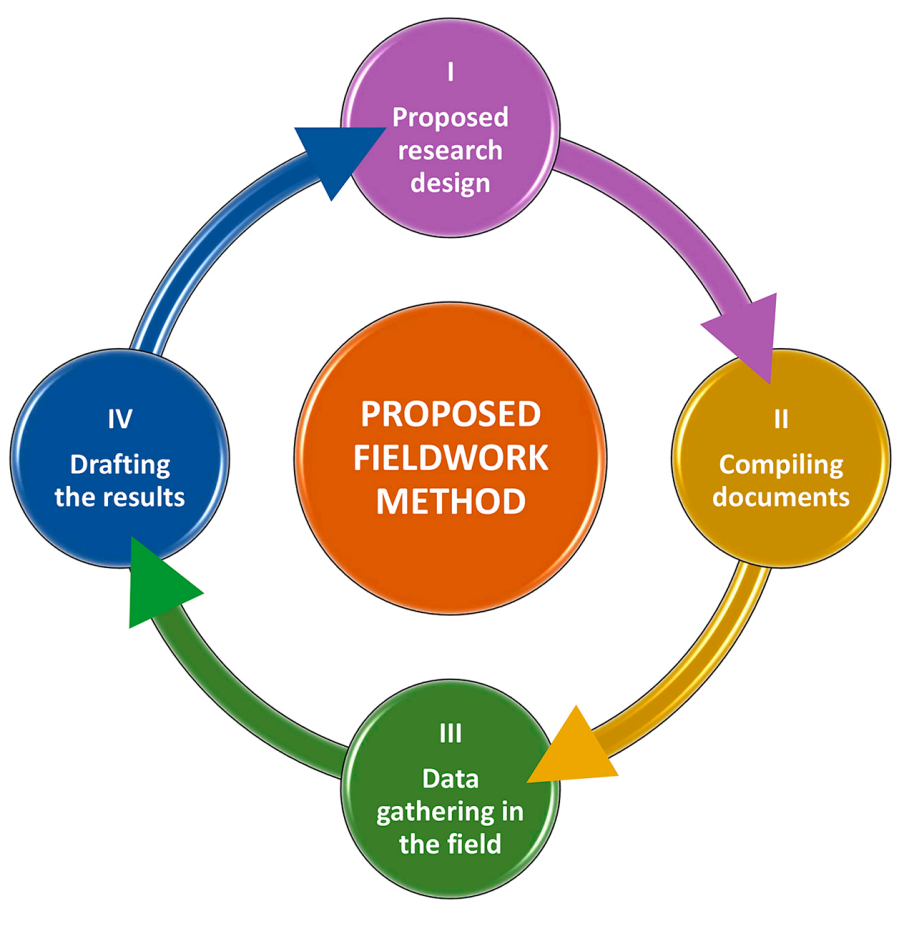

Own elaboration

It is important to start by deciding whether to use a quantitative, qualitative or mixed methodology, analysing to what extent each one will guarantee data of a sufficiently high standard to meet the established objectives and for meaningful conclusions to be reached. The most common steps in fieldwork are:

I. To identify or propose a research topic and to formulate a hypothesis. These are key aspects, requiring a state-of-the-art analysis to build up in-depth information on the subject. In other words, substantial preliminary efforts must be dedicated to collecting, reading and systematizing existing published information.

II. To compile documentary information prior to the field trip, e.g. literature on the subject, case studies, statistics, maps etc.

III. To observe and collect field data, differentiating among quantitative, qualitative and mixed data. This encompasses many possibilities: information and opinions from interviews or surveys, physical samples collected for subsequent laboratory analysis, counts, inventories, etc. As mentioned earlier, fieldwork involves activities in the field, studying real scenarios which may 
enrich or even alter the study's initial premises or posed hypotheses. Through the increased autonomy and group debate that it fosters, fieldwork contributes to meaningful learning by validating or amending prior assumptions.

IV. To draft and present the results. A fieldwork trip also includes the students' defence of the results. Maps are one of the most comprehensive tools in geographical analyses as representations of the spatial distribution of social and environmental data. Information from aerial photographs or satellite images can contribute to the development of thematic maps, drawn up as a result of the fieldwork. Such data is available through ICTs and websites (like IDEIB, https://ideib.caib.es/ visor/, for Mallorca and the other Balearic Islands), processable using GIS technologies.

\subsection{Proposed guidelines for fieldwork}

In the case of a hypothetical-deductive methodology-the most commonly used method in social science research-the guidelines (Cloke et al., 2004; Clifford, French, \& Valentine, 2010) to follow are shown in Table 2.

Table 2. Guidelines for a hypothetical-deductive methodology in social science

\begin{tabular}{|c|c|c|}
\hline \multicolumn{3}{|r|}{ Steps to follow } \\
\hline \multirow{6}{*}{ I } & 1 & Delimiting the work, study or research topic. \\
\hline & 2 & Formulating research questions. \\
\hline & 3 & Defining objectives and hypotheses (e.g. from a problem-based learning perspective). \\
\hline & 4 & Establishing the territorial scope of the study. \\
\hline & 5 & $\begin{array}{l}\text { Selecting a sample for the study: observational transects-from urban walks along streets to roads or paths } \\
\text { crossing wild landscapes-, interviewing people, conducting questionnaires, etc. }\end{array}$ \\
\hline & 6 & $\begin{array}{l}\text { Drafting a methodological guide and outlining the procedures to be followed in order to foster direct } \\
\text { observation and/or participative observation. }\end{array}$ \\
\hline \multirow[t]{2}{*}{ II } & 7 & $\begin{array}{l}\text { Preparing a dossier of documents: articles, maps, statistics, etc. This material will be useful if further } \\
\text { research on the subject is intended. In teaching activities, this dossier will contain work materials for the } \\
\text { students doing the fieldwork. }\end{array}$ \\
\hline & 8 & $\begin{array}{l}\text { Preparing data-collection sheets; for instance, preparing questions to steer the conversation in the case } \\
\text { of in-depth interviews or questionnaires. }\end{array}$ \\
\hline III & 9 & $\begin{array}{l}\text { The following steps should include the students' presentation of the results as part of the evaluation } \\
\text { process. } \\
\text { Data-collection in the field. Through observation by the participants, information and opinions of } \\
\text { many kinds (qualitative and quantitative data) can be collected in different ways (interviews, surveys or } \\
\text { physical sampling, counts, inventories, etc.) for subsequent processing in the laboratory. }\end{array}$ \\
\hline \multirow{7}{*}{ IV } & 10 & $\begin{array}{l}\text { Storage and systematic pre-processing of the samples and collected data. For instance, extracting data } \\
\text { from interviews or questionnaires. }\end{array}$ \\
\hline & 11 & $\begin{array}{l}\text { Processing the qualitative or quantitative data collected in the field, using statistical or computer processing } \\
\text { programmes; i.e. ATLAS.ti, SPSS, or simply spreadsheets. An example of quantitative data-processing is } \\
\text { the establishment of correlation patterns or even explanatory factors for a set of collected variables. }\end{array}$ \\
\hline & 12 & Using the collected materials to make generalizations. \\
\hline & 13 & Making thematic maps of the detected data and phenomena. \\
\hline & 14 & $\begin{array}{l}\text { Discussing the validity of the hypotheses and corroborating, ratifying or rejecting them, comparing them } \\
\text { with known theories. }\end{array}$ \\
\hline & 15 & Reaching conclusions with regard to the established the objectives. \\
\hline & 16 & $\begin{array}{l}\text { Finally, if the research has applied purposes, proposals for action, aimed at improving or altering the } \\
\text { analysed reality through a problem-solving approach. In the field of spatial tourism planning, for instance, } \\
\text { the purpose of applied geography is to contribute to the design of public policies able to mitigate the } \\
\text { problems of the Anthropocene, such as socio-spatial restructuring processes following the COVID-19 crisis. }\end{array}$ \\
\hline
\end{tabular}

Own elaboration

When these guidelines are put into practice, participatory methods will be required, where students assume an autonomous role in learning. 


\subsection{Organizational teaching models}

In accordance with the classification by France and Haigh (2018) shown in section 1.2, the aim of this paper is to focus on activities that foster student autonomy. Teachers play a decisive role in types of student involvement, and inquiry-based approaches are useful in fostering student autonomy. This calls for the design of a teaching process that features different levels of student responsibility and involvement in their own learning process at an individual and group level.

For example, if the fieldwork is aimed at identifying and analysing the spatial pattern of certain Anthropocenic processes, some basic indications by teachers will be needed. There are various ways of doing this but, in this case, we offer students a series of basic conceptual ideas for locating a case study and the basic data needed to analyse it. The steps in the educational process are shown in Table 3.

Table 3. Educational steps in geographical fieldwork

\begin{tabular}{|c|c|}
\hline \multicolumn{2}{|r|}{ Aspects to be considered } \\
\hline 1 & The establishment of a basic conceptual framework by teachers. \\
\hline 2 & The assignment of aspects to be worked on or subtopics to each group of students. \\
\hline 3 & $\begin{array}{l}\text { Reaching an agreement on each study group's different levels of involvement (e.g. prior preparation by everyone, } \\
\text { peer explanations, etc.). }\end{array}$ \\
\hline 4 & $\begin{array}{l}\text { Reaching a decision on the evaluation criteria for the whole process (preparation, execution, defence of the } \\
\text { results) and making these criteria known. }\end{array}$ \\
\hline 5 & $\begin{array}{l}\text { Preparing basic qualitative and quantitative sources of information for the students to consult as essential } \\
\text { secondary sources in their diagnosis of their topic. }\end{array}$ \\
\hline 6 & $\begin{array}{l}\text { The teachers' preparation of the basic logistics for the fieldwork activity and its organization, structure, deadlines, } \\
\text { etc. An explanation of all this to the students. }\end{array}$ \\
\hline 7 & Defining and agreeing on the work to be done by each group and on each topic. \\
\hline 8 & $\begin{array}{l}\text { Strategies for the presentation of each group's work to the other students, with the option of peer assessment, or } \\
\text { the inclusion of possible stakeholders or interest groups in the process. }\end{array}$ \\
\hline
\end{tabular}

Own elaboration

Through clear planning of the above steps, it is possible to agree on different stages in the fieldwork, deciding on the places and even the times for each of the presentations of different topics by the groups. During the field trip, at each stage or stop on the route, although the teacher might give basic indications, each of the study groups is responsible for explaining what they have prepared to the other students, using whatever materials they deem appropriate. The teacher fulfils a double role, as a guide in the fieldwork while also providing any complementary information that might have been overlooked. They will never be the main protagonist.

Once the allotted time for each topic and visit has come to an end, the groups should be allowed to work on their own in the field, completing their research with whatever methods they deem necessary: direct participative observation, individual interviews, field notes, a photographic report, etc.

Through this type of design, several related variables (scale, time, the complexity of a problem) can be modified. Thus, depending on the available time or the potential places that can be visited and surveyed, the level of detail and the complexity of the topic to be worked on can be modified. Cooperative work by different groups of students enriches the process for all of them and it opens up the possibility of alternative fieldwork designs. A design covering a wide range of topics is possible, albeit working at a basic level to facilitate a broad holistic knowledge, complementing some topics with others. In contrast, if more time is available or the possibility of several thematic field trips is offered, each group can present their subject in greater depth within a general common framework. Work on complementarity, interrelations and holistic analyses can be carried out at subsequent sessions, when each group looks for synergies and the teacher supervises these interrelations, suggesting or facilitating them if necessary. This is when the necessary sources should be outlined for the completion of a final task for the teacher or social agents, whether it is an oral presentation, project, report or poster.

\subsection{Applying the proposed guidelines to a practical exercise}

Our proposed methodology shows how field trips can be organized by applying hypothetical-deductive analytical methods. It fosters a series of skills, aimed at boosting student autonomy and promoting a 
raised environmental awareness in order to tackle problems associated with human-driven global change, bringing students into direct contact with reality in a meaningful learning process.

Through a practical exercise, we demonstrate how fieldwork can be applied to a set of previously established topics: 1) the interrelations between increasing fuel consumption by tourist air traffic, global warming, rising sea levels and beach management, bearing in mind that beaches are key assets for mass sun and sand tourism; 2) changes in land use at tourist destinations that result in urban sprawl, such as extensions to airports and the restructuring of the built environment; and 3) the role of regional and urban planning in tackling global change.

We apply the guidelines outlined above to a real case study of Mallorca. As a first step, the teacher must give the students a general description of the case study, an outline of the theoretical framework and details of the research sources and methodology.

\subsubsection{General description of the case study and the theoretical framework}

Insularity limits the availability of resources, accentuating the problems of the Anthropocene. Mallorca is a good example, and its inhabitants have reacted to these constraints by calling for a curb on urban tourism growth (Valdivielso \& Moranta, 2019). Large airports close to mass tourism resorts highlight the link between aviation and rising sea levels. Several related topics can be used in fieldwork, such as how to manage sustainable beach tourism, given the threat of rising sea levels; or the interpretation of land uses (urban sprawl toward the island's remaining wetlands and its coastline) for the restructuring of accommodation and transport facilities, particularly the airport; or the regulation of land uses at an urban and regional level.

For the teaching activity, coastal tourist resorts are used in order to explore what changes might be made to deal with current scenarios of global change. In this case, the factors to consider are the changes brought about by the 2020 COVID-19 pandemic. At a hypothetical level, these tourist destinations face similar problems, due to a combination of rising sea levels, growing travel problems for health reasons, and fuel constraints for air traffic.

Mallorca has 301,000 tourist beds in hotels and tourist apartments of varying kinds (Agència d'Estratègia Turística de les Illes Balears [AETIB], 2019). This does not include the housing accommodation used for tourism purposes, which has given rise to a process of commodification. This share is estimated as accounting for 101,215 beds, based solely on accommodation marketed by Airbnb (https://twitter.com/ terraferida). Beaches are the island's main tourist attraction, and the biggest tourist resorts are located close to them. There is an estimated ratio of $1.68 \mathrm{~m}^{2}$ of beach per tourist bed, based on the useful surface area of all the island's beaches and the peak tourist season (with a peak of $1,477,157$ tourists in 2017), while the optimum ratio would be $15 \mathrm{~m}^{2} /$ person (Consell Insular de Mallorca, 2018). To tackle the problem of overtourism, plans and laws have been passed at a regional spatial planning level directed at curbing tourist beds (Blázquez-Salom, Blanco-Romero, Vera-Rebollo, \& Ivars-Baidal, 2019) and at managing the coastline, with particular attention to beaches (Mir-Gual, Pons, Roig-Munar, \& Martín-Prieto, 2012).

For this small island, with visitor numbers of nearly 12 million tourists in 2018 (AETIB, 2019), the COVID-19 crisis will once again lead to the destruction and restructuring of wealth, temporarily overcoming some of the impacts and then leading to a new stage of capital circulation and accumulation (Murray et al., 2017). Prior to the COVID-19 outbreak and the ensuing crisis, the company that runs the airport under a public-private partnership called for its extension from a current capacity of nearly 30 million passengers in $2018^{3}$ to a scenario of 34 million in 2025 (Dirección General de Aviación Civil, 2020). As far as aviation emissions are concerned- the main source of greenhouses gas emissions for the world tourism industry (Lenzen et al., 2018)-, the airport's proximity to big tourist resorts is a useful teaching resource in fieldwork.

The urban beaches typically associated with mass tourist resorts are correlated with the highest erosion rates (Martín, Carreras, Pons \& Almaraz, 2020). This is due to their artificialisation through the construction of buildings and promenades on dune systems, infrastructure on the beach itself, sand cleaning machines, and changes to the longshore drift linked to the construction of new marinas that act as a sediment traps (Martín et al., 2016). The evolution of Mallorca's busiest beaches, Platja de Palma and Cala Millor, has been surveyed using topo-bathymetric sampling, wave gauge monitoring and shoreline

3 Air traffic statistics by AENA, available online http://www.aena.es/csee/Satellite?pagename=Estadisticas/Home 
variation mapping inferred from video monitoring stations. The results indicate a coastal retreat of 7 to 50 metres, equivalent to half the present-day aerial beach surface, according to 21 st century sea level and wave projections under considered climate scenarios (Enríquez, Marcos, Álvarez-Ellacuría, Orfila \& Gomis, 2017). These selected beaches are located in built-up areas, backed by walls, with limited possible landward migration of the shoreline. The COVID-19 health crisis has forced the public authorities to limit the number of visitors to beaches, with the recommendation of mechanical sand screening or sieving systems (Ministerio de Sanidad, 2020). From a tourist point of view, these two resorts are typical examples of coastal mass tourist destinations.

Platja de Palma is the most important tourist resort in the Balearic Islands, dating back to the 1960s. It stands close to the island's airport, with nearly 50,000 tourist beds (Yrigoy, 2014). Cala Millor is a tourist resort initially developed in the 1990s (Pons, Rullan, \& Murray, 2014), later than Platja de Palma due to its distance of $70 \mathrm{~km}$ from the airport. This second area is characterised by hotels with a total capacity of 28,400 beds, according to the Balearic Tourist Accommodation Catalogue (CAIB, 2015), surrounded by the Son Moro and Port Verd districts.

\subsubsection{Research sources and the methodology for the practical exercise}

The exercise begins with the field trip's design in the classroom, establishing the procedures and other aspects. In accordance with our proposed guidelines and emphasis on student autonomy, the students must be involved in the design instead of listening to explanations, as occurs with other staff-led activities. This means that a dossier must first be prepared with articles, maps, statistics and so on, together with a research aide-mémoire. For this study of Mallorca's tourist resorts, the teachers will outline some available resources: previous studies of the areas (Yrigoy, 2015, Casañas, 2017; Enríquez, et al., 2017), cartographic viewers (https://ideib.caib.es/visor/), statistics (AETIB, 2019; http://www.aena.es), urban and tourism planning data (Consell de Mallorca, 2015; Consell de Mallorca, 2020), etc.

To analyse the links between tourism and global change, for our case study of Mallorcan tourist resorts, the following steps were defined: the formulation of a hypothesis, the preparation of a detailed dossier including sources of information (data collection), and the definition of research methods, such as participatory observation or mapping. For instance:

- To work on the topic of beach management, a hypothesis must be formulated on the interrelations between tourist air traffic, global warming, and rising sea levels. For example, substantial statistical data can be found on the correlation between concentrations of $\mathrm{CO} 2$ in the atmosphere, temperatures, rising sea levels and their effect on the analysed beaches (Figures 2 and 3).

Figure 2. Present-day shoreline (in yellow) and landward migration (in red) in the worst-case scenario by the end of the 21st century in Platja de Palma

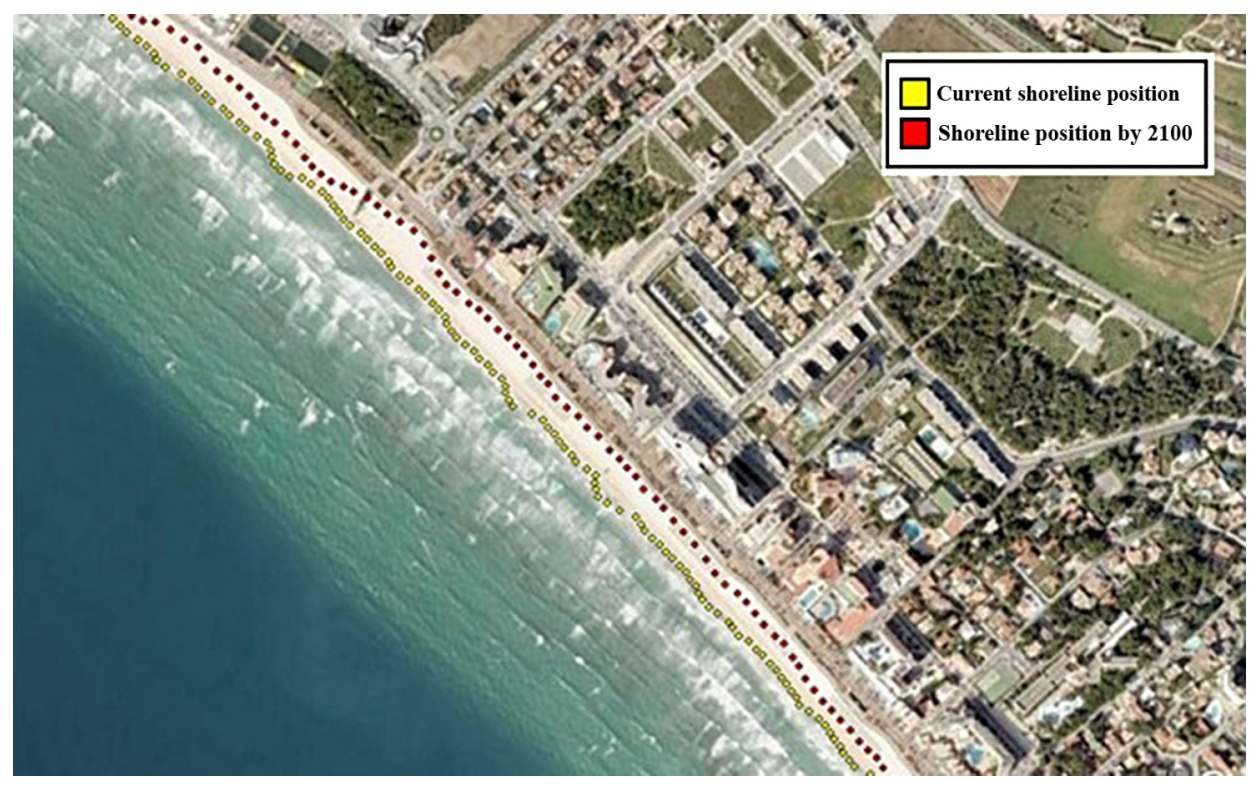

Source: Enríquez et al., 2017 
Figure 3. Tourist use of Platja de Palma beach

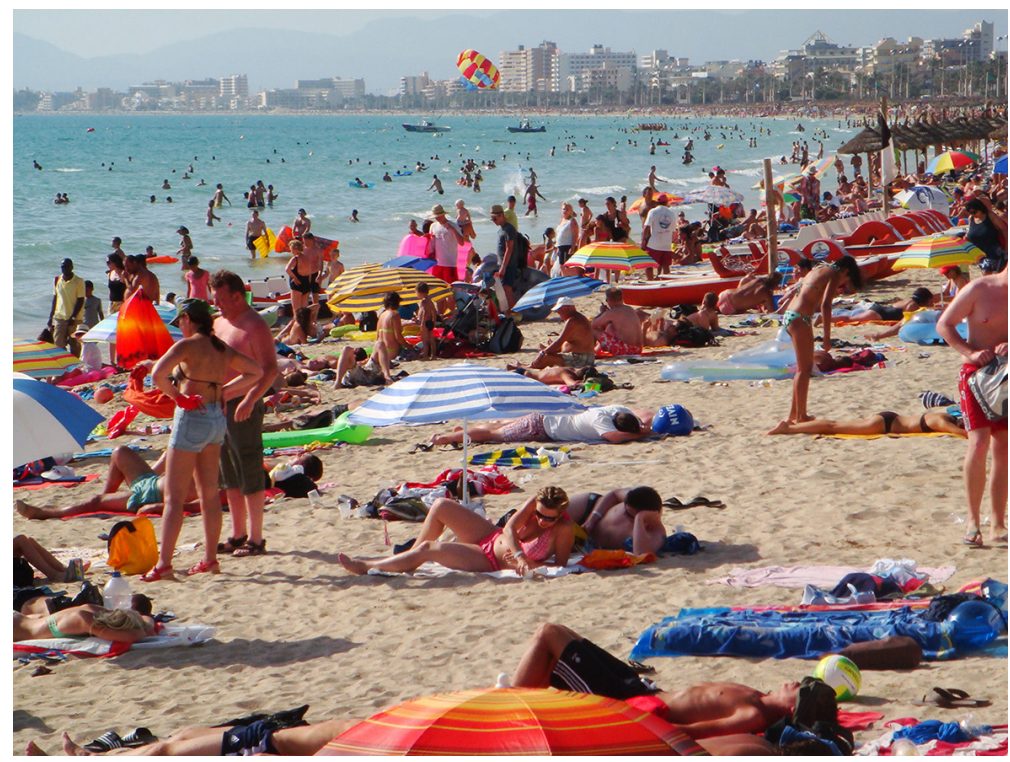

Source: Macià Blázquez-Salom, July 28th 2019. Own elaboration

- To study beach management, data or samples collected in the field can be related to aircraft movements at Palma Airport as the generators of greenhouse gases; surveys can be conducted of visitor numbers to beaches (Figure 3); or hotel managers can be interviewed to find out their concerns regarding the environment, the island's shrinking beaches etc.

- To study changes in land use, participatory observation is one of the most effective methods in fieldwork research, as with the above study of coastal management. The students should be asked to design surveys in order to boost their autonomy (e.g. surveys of groundwater levels and the quality of the water, or biodiversity inventories of the remaining wetlands, threatened by urban sprawl and extensions to the airport). By contrasting coastal management documents and the demarcation of the coastline shown in them with the reality (Figure 4), group debates can be fostered which contribute to meaningful learning by validating or correcting assumptions.

Figure 4. Waterfront boundary marker (the small pyramid circled in red in the picture) at Port Verd. Despite this, the terrace of a beach club prevents public access to the coast.

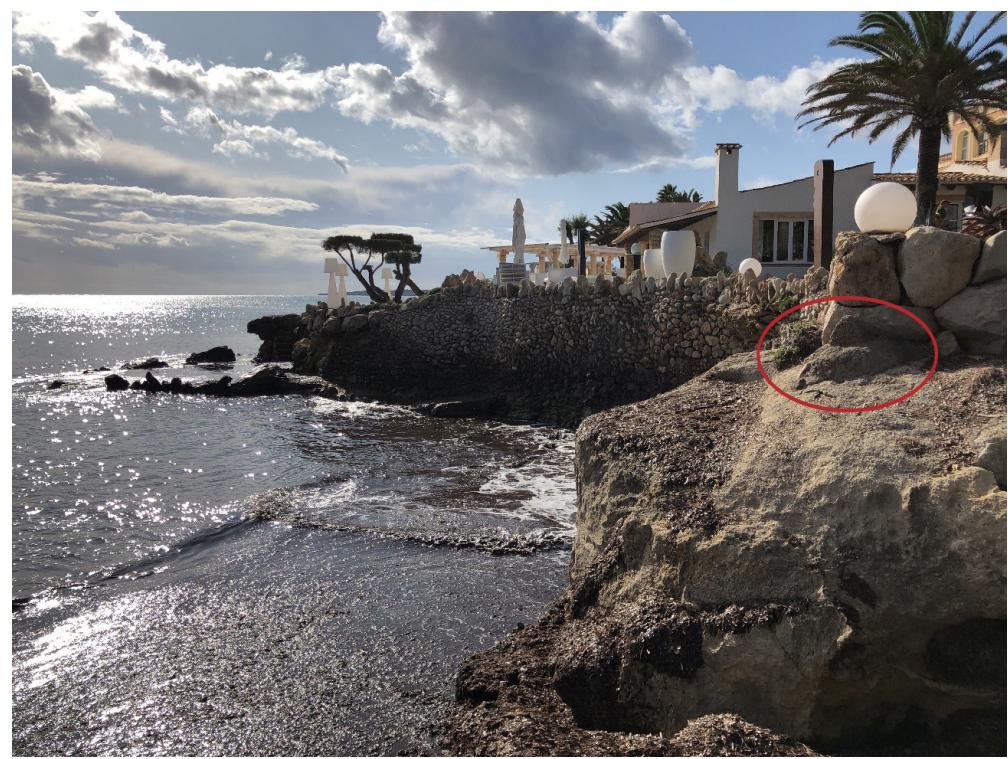

Source: Macià Blázquez-Salom, September $8^{\text {th }}$ 2019. Own elaboration 
- Maps are a good example of the materials that can be created as a result of fieldwork. Student autonomy can be boosted by analysing geographical patterns for the three selected topics. Mapping can be done directly, e.g. by mapping the area occupied by a beach or the infrastructure needed to manage it (Figure 5); the distance between the waterfront and different land uses, such as residential uses (Figure 6) or tourist accommodation; or air traffic arrival and departure flows.

Figure 5. Concrete blocks used to prevent the erosion of Cala Bona beach

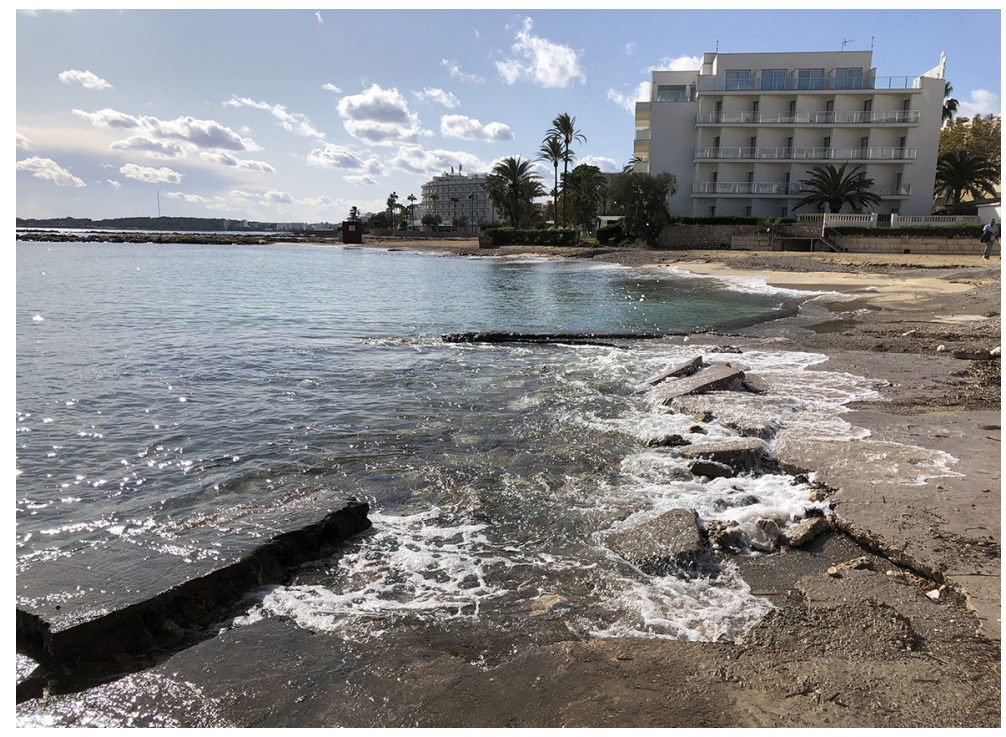

Source: Macià Blázquez-Salom, September $8^{\text {th }}$ 2019. Own elaboration

Figure 6 . The proximity of the waterfront to residential land uses, with less proximity in the case of tourist accommodation due to the demand for more available public space on beaches

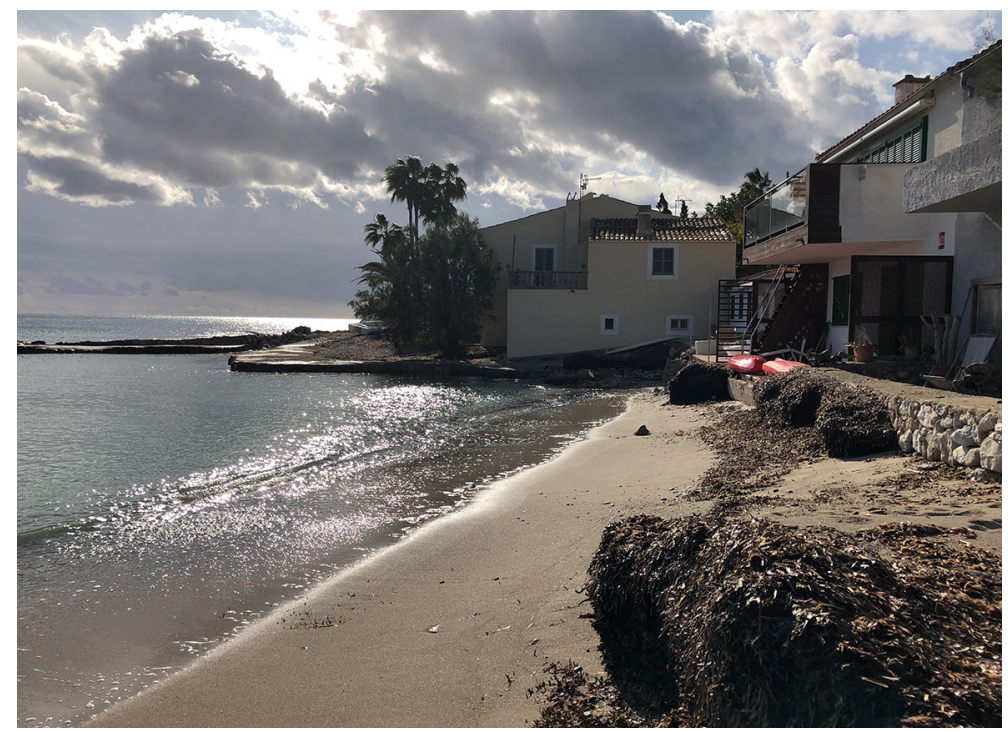

Source: Macià Blázquez-Salom, September $8^{\text {th }}$ 2019. Own elaboration

- Fieldwork is particularly useful in analyses of changes in land use in the built environment. Platja de Palma and Cala Millor are both designated mature tourist resorts for regional planning purposes due to their congestion, with a high density of tourist beds, environmental degradation and obsolete buildings and infrastructure. This designation was applied after the 2008 crisis to allow for the restructuring of hotel facilities and to relax certain urban planning constraints. The COVID-19 pandemic has served to reinforce these policies, prioritizing short-term results instead of trying to mitigate or adapt to the effects of global change. 
- Finally, fieldwork can be used in studies of urban and tourism planning to identify hotel buildings that have recently been or that are still being adapted or refurbished in accordance with new regulatory frameworks aimed at facilitating their modernization or new system of management through the creation of condo-hotels or their conversion into apartments. In the case of Platja de Palma, a new Integral Restructuring Plan was approved in 2015 as part of a political commitment to tackle the 2008 systemic crisis (Yrigoy, Artigues \& Blázquez-Salom, 2013 and 2015). This urban planning instrument's detailed maps can be used as a source of information to understand spatial restructuring process, such as changes in the use of hotels or new urban sprawl due to new development projects approved as a result of the former crisis. Even though this urban area is located on a coastal system of sand dunes, a restinga or a coastal ridge between the wetland and the sea, this instrument does not take climate change into consideration at all.

\section{Discussion}

The fieldwork proposed in this article, based on specific examples and exercises, helps to foster learning skills, thus confirming our initial hypothesis where we defend fieldwork's contribution to scientific headway in tourism geography. Our teaching experience corroborates the following: a) improved student autonomy in analysing realities, thus facilitating meaningful learning b) a raised environmental awareness in order to tackle the problems of global change brought about by humankind during the Anthropocene; c) the capacity to explore realities, through direct contact in the field, and hence to contribute to a search for solutions to the current socio-ecological scenario.

Thus this paper has confirmed the usefulness of fieldwork in enriching how the conceptual and theoretical rudiments of tourism geography are taught, further to what other authors have already said (France and Haigh, 2018; Kent et al., 1997; Martínez and Yubero, 2020). In fieldwork, the basic criteria developed by Kent, Gilbertson \& Hunt (1997) for classifying learning criteria can be applied, promoting student autonomy and management of their own role in learning. Fieldwork also contributes to the learning methods defined by France and Haigh (2018), based on teamwork and project-oriented, enquiry-based approaches that connect theory and practice. This problem-based learning (PBL) process encourages independence and a critical analysis of realities (Pawson, et al. 2006; Thomas, 2009). The design of practical guidelines, such as ours, can be used to promote meaningful learning (Torrisi-Steel, 2009), fostering autonomous and participatory learning competences and skills where students take responsibility for what they learn.

The tourist industry shuns any reference to links between tourism and global change, upholding virtues such as the generation of enjoyable leisure experiences. In this context, tying tourism in with the Anthropocene is a useful teaching exercise that promotes greater sensitivity to nature and an active interest in trying to find a solution to the socio-ecological problems caused by humankind (Prince, 2020). The COVID-19 pandemic demonstrates human dependence on conserving an ecological balance even more strongly (Gibb, et al., 2020).

By using fieldwork to explore realities, following the guidelines established in this paper, students can take responsibility for research. As a teaching strategy, fieldwork puts students into direct contact with real situations (Santiago, 1998), allowing them to interpret and analyse them from a scientific perspective (Sánchez \& Godoy, 2002) in a meaningful learning process where practice is given in the cognitive processes needed for problem-solving tasks (Torrisi-Steele, 2009). As we show, direct observation offers an opportunity to gain an insight into the realities of tourism geography and the problems of the Anthrophocene. In our experience, students are capable of testing hypotheses, explaining geographic phenomena and coming up with proposals to tackle problems, through methods such as urban and regional planning.

\section{Conclusions}

Through in-depth, rigorous tests of the proposed fieldwork methodology with our students, we were able to ratify our initial hypothesis. We demonstrate fieldwork's usefulness, particularly in studying the links between tourism and the Anthropocene at mass tourist destinations. The methodology -which we apply to Mallorca as a case study, although it can equally well be transposed to other geographical settings- demonstrates fieldwork's effectiveness in encouraging students to take responsibility for what they learn in meaningful contexts and in fostering an awareness of humankind's responsibility for finding 
a solution to the crises of the Anthropocene, in addition to highlighting the usefulness of direct contact with realities as a means of gaining a better understanding of them.

In terms of our initial aims, we have achieved our first aim by demonstrating that fieldwork can contribute to analyses of the relations between tourism and the Anthropocene, helping to test out theories through a comparison with real situations. For this group activity, where the spotlight is cast on the role of the students, many possible topics can be studied, such as global warming processes caused by fossil fuels and the ensuing consequences on sea levels and beach management, given the importance of beaches in mass sun and sea tourism.

As for our second aim, the design of methodological tools to enrich fieldwork activities, hypotheticaldeductive methods are scientifically sound, useful means of analysis in tourism geography and our guidelines can be extrapolated to similar teaching and learning processes. Fieldwork helps to develop different skills and competences, such as observation, analysis, summarization, autonomy, sampling techniques and the general application of acquired knowledge (Torrisi-Steele, 2009), in our case instilling an interest in the link between global change and tourism.

Our third aim was to test the practicality of our proposed methodology by applying it to a case study, specifying the steps to be taken, based on the practical guidelines in Table 2. This allowed us to test out a conceptual design where theoretical knowledge can be contrasted with the spatio-temporal realities of spatial construction through diachronic processes. Through the fieldwork activities, encounters with stakeholders can be facilitated, a holistic vision can be gained of complex phenomenon, and important insights can be achieved into situations occurring on the Earth's surface at a spatial level, in addition to spatial disparities, changes and possible causal interrelations.

One limitation of our proposed methodology is the role of the teacher. Paradoxically, giving the students greater responsibility calls for more commitment on the part of the lecturer, since greater dedication is needed than in the classroom. The teacher is no longer the transmitter of conceptual information but a guide who mediates in a meaningful learning process. As the main responsibility for the learning process is delegated to the students as individuals and as groups, multiple-criteria assessment methods must be used.

A second aspect to consider in future research is the level of assimilation of learning outcomes. The acquired skills can be evaluated through improvement indicators and criteria like the application of the developed methods, employability, etc. In future research, a detailed study should be made of the application of our proposed learning experience to groups of undergraduate students.

Lastly, the uncertain economic consequences of the COVID-19 crisis are having huge socio-spatial repercussions on mass tourist destinations, like Mallorca, an island that can be considered a Ground Zero in this crisis. Within this context, fieldwork is an all-important tool in teaching tourism geography and in analysing the restructuring of tourist resorts within the framework of the Anthropocene's human-driven changes.

\section{Funding}

This research contributes to the projects: "Overtourism in Spanish Coastal Destinations. Tourism Degrowth Strategies" (RTI2018-094844-B-C31) and "Inland tourism in Spain: Challenges, valorisation and strategies in the face of changing situations and crises for boosting tourism products and destinations. Case dynamics" (CSO2016-74861-R), State R+D+I program oriented toward society's challenges, Ministerio de Ciencia, Innovación y Universidades, Agencia Estatal de Investigación and European Regional Development Fund of the European Union.

\section{References}

Agència d'Estratègia Turística de les Illes Balears (AETIB) (2019). El turisme a les Illes Balears. Anuari 2018. Palma (Mallorca): Agència d'Estratègia Turística de les Illes Balears, Vicepresidència i Conselleria d'Innovació, Recerca i Turisme. Govern de les Illes Balear. Retrieved from http://www.caib.es/sites/ estadistiquesdelturisme/ca/anuaris_de_turisme-22816/archivopub.do?ctrl=MCRST865ZI290987\&id= $\underline{290987}$

Antolín, J.E. (2019). El ecologismo en la época de la pospolítica. Del ecologismo militante al emocional: límites estructurales del discurso ecologista. Ecología Política, 58, 19-26. 
Amat, X. (2013). La resiliencia del territorio alicantino (Tesis doctoral). Universidad de Alicante. Alicante. Biggs D., Hall M., \& Stoeckl, N. (2011). The resilience of formal and informal tourism enterprises to disasters: reef tourism in Phuket, Thailand. Journal of Sustainable Tourism, (1), 1-21.

Benach, N. (2017). William Bunge. Las expediciones geográficas urbanas. Barcelona: Icaria, Espacios Críticos.

Blanco-Romero, A. (2019). Tourism degrowth. In E. Cañada (Coord.), Tourism in the geopolitics of the Mediterranean. Barcelona: Alba Sud.

Blanco-Romero, A., \& Blázquez-Salom, M. (2021). Inland Territorial and Tourism Resilience in a Polarized World. In C. Bevilacqua, F. Calabrò, L. Della Spina (Eds.), New Metropolitan Perspectives. NMP 2020. Smart Innovation, Systems and Technologies, 178. https://doi.org/10.1007/978-3-030-48279-4_178

Blázquez-Salom, M., Blanco-Romero, A., Vera-Rebollo, F., \& Ivars-Baidal, J. (2019). Territorial tourism planning in Spain: from boosterism to tourism degrowth?. Journal of Sustainable Tourism, 27(12), 1764-1785. https://doi.org/10.1080/09669582.2019.1675073

Bohórquez, L. (28/04/2020). Baleares, "zona cero" de la crisis pospandemia. El País. Retrieved from https://elpais.com/espana/2020-04-27/baleares-zona-cero-de-la-crisis-pospandemia.html

Breitbart, M.M. (2010). Participatory Research Methods. In N. Clifford, S. French, and G. Valentine (Eds.), Key Methods in Geography (second edition) (pp. 141-156). London: SAGE Publications.

Büscher, B., \& Fletcher, R. (2020). The conservation revolution. Radical ideas for saving nature beyond the Anthropocene. London: Verso.

Casañas, F. (2017). El procés de litoralització a la Marina de Llucmajor; Transformació dels assentaments tradicionals i la consolidació del contínuum urbà de segona residencia. Final Degree Project in Geography, Geography Department, University of the Balearic Islands. Retrieved from https://dspace.uib.es/ xmlui/handle/11201/2173

Comunidad Autónoma de las Islas Baleares [CAIB] (2015). Balearic Islands Tourist Accommodation Catalogue. Palma: Caib.

Comunidad Autónoma de las Islas Baleares [CAIB] (2020). Impacte economic a Balears del Covid 19. Palma: Caib. Retrieved from: https://www.caib.es/pidip2front/jsp/adjunto? codi=2418810\&idioma=ca

Consell de Mallorca (2015). Acord d'aprovació definitiva amb prescripcions del Pla de reconversió integral de la Platja de Palma. Retrieved from: http://www.caib.es/eboibfront/ca/2015/10311/565116/ acord-d-aprovacio-definitiva-amb-prescripcions-del

Consell de Mallorca (2020). Acord d'aprovació definitive del Pla d'Intervenció en Àmbits Turístics de Mallorca. Retrieved from https://www.conselldemallorca.cat/info-pub-ut?id_section=7681\&action=news\&id_ article $=32416 \&$ \&id_parent $=19162$

Clifford, N., French, S., \& Valentine, G. (2010). Key Methods in Geography. London: SAGE Publications.

Cloke, P., Cook, I., Crang, P., Goodwin, M., Painter, J., \& Philo, C. (2004). Practising Human Geography. London: SAGE Publications.

Consell Insular de Mallorca. (2018). Aprovació inicial del Pla d'Intervenció en Àmbits Turístics de Mallorca (PIAT). Butlletí Oficial de les Illes Balears, 93, 28/07/2018. Retrieved from http://www. conselldemallorca.net/? \&id_parent=444\&id_class=532\&id_section=15489\&id_son=19134

Cork, S. (2009). Brighter prospects: Enhancing the resilience of Australia. Melbourne: Australia21.

Crutzen, P.J. (2002). Geology of mankind: The Anthropocene. Nature, 415:23. https://doi. org/10.1038/415023a

Dirección General de Aviación Civil (2020). Documento de Regulación Aeroportuaria. Madrid: Dirección General de Aviación Civil, Secretaria de Estado de Infraestructuras, Transporte y Vivienda, Secretaría General de Transporte, Ministerio de Fomento. Retrieved from https://www.seguridadaerea.gob.es/ media/4628954/dora_mfom.pdf

Enríquez, A.R., Marcos, M., Álvarez-Ellacuría, A., Orfila, A., \& Gomis, D. (2017). Changes in beach shoreline due to sea level rise and waves under climate change scenarios: application to the Balearic Islands (western Mediterranean). Nat. Hazards Earth Syst. Sci., 17, 1075-1089. https://doi.org/10.5194/ nhess-17-1075-2017 
Fletcher, R. (2007). The Fieldworker's Magic. Anthropology News, 48(2), 19-19. https://doi.org/10.1525/ an.2007.48.2.19

Fletcher, R., Murray, I., Blanco-Romero, A., \& Blázquez-Salom, M. (2019). Tourism and degrowth: an emerging agenda for research and praxis. Journal of Sustainable Tourism, 27(12), 1745-1763. https:// doi.org/10.1080/09669582.2019.1679822

France, D., \& Haigh, M. (2018). Fieldwork@40: fieldwork in geography higher education. Journal of Geography in Higher Education, 42(4), 498-514. https://doi.org/10.1080/03098265.2018.1515187

Gibb, R., Redding, D.W., Chin, K.Q. et al. (2020). Zoonotic host diversity increases in human-dominated ecosystems. Nature. https://doi.org/10.1038/s41586-020-2562-8

Gössling, S., Scott, D., \& Hall, C.M. (2020). Pandemics, tourism and global change: a rapid assessment of COVID-19. Journal of Sustainable Tourism. https://doi.org/10.1080/09669582.2020.1758708

Haigh, M. J. (2017). Connective practices in sustainability education. Journal of Applied Technical and Educational Sciences, 7(4), 6-30.

Hopkins, R. (2010). Localisation and resilience at the local level. The case of Transition Town Totnes (Devon, UK). PhD. University of Plymouth.

Hudson, R. (2010). Resilient regions in an uncertain world: wishful thinking or a practical reality? Cambridge Journal of Regions, Economy and Society, 3, 11-25. https://doi.org/10.1093/cjres/rsp026

Kallis, G., Kostakis, V., Lange, S., Muraca, S., Paulson, S., \& Schmelzer, M. (2018). Research on degrowth. Annual Review of Environment and Resources, 43(1), 291-316. https://doi.org/10.1146/annurevenviron-102017-025941

Kent, M., Gilbertson, D.D., \& Hunt, C.O. (1997). Fieldwork in Geography Teaching: a critical review of the literature and approaches. Journal of Geography in Higher Education, 21, 3, 313-332. https://doi. org/10.1080/03098269708725439

Kropotkin, P. A. (1885). What Geography Ought to Be. The Nineteenth Century, 18, 940-956.

Lenzen, M., Sun, Y., Faturay, F., Ting, Y., Geschke, A., \& Malik, A. (2018). The carbon footprint of global tourism. Nature Clim Change, 8, 522-528. https://doi.org/10.1038/s41558-018-0141-X

Martín, J. A., Roig-Munar, F. X., Rodríguez-Perea, A., Mir-Gual, M., Pons-Buades, G. X., \& Gelabert-Ferrer, B. (2016). La erosión histórica de la playa de sa Ràpita (S. Mallorca). Investigaciones Geográficas, (66), 135-154. https://doi.org/10.14198/INGEO2016.66.08

Martín, J.A., Carreras, D., Pons, G.X., \& Almaraz, A. (2020). Shoreline historical evolution (1956-2015) of beaches of Menorca (Balearic Islands). In G. Malvárez and F. Navas (Eds.), Global Coastal Issues of 2020. Journal of Coastal Research, Special Issue No. 95, (pp. 563-567). https://doi.org/10.2112/SI95$\underline{110.1}$

Martínez-Hernández, C., \& Yubero, C. (2020). Explaining Urban Sustainability to Teachers in Training through a Geographical Analysis of Tourism Gentrification in Europe. Sustainability, 12, 67. https:// doi.org/10.3390/su12010067

McMorran, C. (2015). Between fan pilgrimage and dark tourism: Competing agendas in overseas field learning. Journal of Geography in Higher Education, 39(4), 568-583. https://doi.org/10.1080/0309826 $\underline{5.2015 .1084495}$

Mínguez, M.C. (2010). El paisaje como objeto de estudio de la Geografía: Un itinerario didáctico en el marco de la Semana de la Ciencia de la Comunidad de Madrid. Revista de Didáctica Geográfica, 11, 37-62.

Ministerio de Sanidad (2020). Recomendaciones para la reapertura de playas y zonas de baño tras la crisis del COVID-19. Retrieved from https://www.mscbs.gob.es/gabinetePrensa/notaPrensa/ pdf/24.05240520094526477.pdf

Mir-Gual, M., Pons, G.X., Roig-Munar, F.X., \& Martín-Prieto, J.Á. (2012). La Ley de Costas española: de su revisión a su grado de aplicación. In A. Rodríguez-Perea, G.X. Pons, F.X. Roig-Munar, J.Á. MartínPrieto, M. Mir-Gual, \& J.A. Cabrera (Eds.), La gestión integrada de playas y dunas: experiencias en Latinoamérica y Europa (pp. 105-122). Palma: Mon. Soc. Hist. Nat. Balears, 19.

Monk, J. (2000). Looking out, looking in: The 'other' in the journal of geography in higher education. Journal of Geography in Higher Education, 24(2), 163-177. https://doi.org/10.1080/03098260050077463 
Morote, A.F. (2019). Las salidas de campo en España como recurso didáctico para la enseñanza de la geografía. Una revisión bibliográfica. Geographicalia, 71, 27-49. https://doi.org/10.26754/ojs_geoph/ geoph.2019714142

Murray, I. (2015). Capitalismo y turismo en España. Del “milagro económico" a la "gran crisis”. Barcelona: Alba Sud. Retrieved from http://www.albasud.org/publ/docs/68.ca.pdf

Murray, I., Yrigoy, I., \& Blázquez-Salom, M. (2017). El papel de las crisis en la producción, destrucción y reestructuración de los espacios turísticos. El caso de las Islas Baleares. Investigaciones Turísticas, 13, 1-29. https://doi.org/10.14198/INTURI2017.13.01

Pawson, E., Fournier, E., Haigh, M., Muniz, O., Trafford, J. \& Vajoczki, S. (2006) Problem-based Learning in Geography: Towards a Critical Assessment ofits Purposes, Benefits and Risks, Journal of Geography in Higher Education, 30, 1, 103-116. https://doi.org/10.1080/03098260500499709

Pedrinaci, E., Sequeiros, L., \& García de la Torre, E. (1994). El trabajo de campo y el aprendizaje de la Geología. Alambique. Didáctica de las ciencias experimentales, 2, 37-46.

Pons, A., Rullán, O., \& Murray, I. (2014). Tourism capitalism and island urbanization: tourist accommodation diffusion in the Balearics, 1936-2010. Island Studies Journal, 9, 2, 239-258.

Prince, S. (2020). From Sustainability to the Anthropocene: Reflections on a Pedagogy of Tourism Research for Planetary Attachment. Journal of Teaching in Travel E Tourism, 20-2020(3), 173-189. https://doi.org/10.1080/15313220.2020.1797608

Reclus, E. (1901). LEnseignement de la géographie. Bruselas: Institute Géographie de Bruxelles.

Sánchez, M., \& Godoy, I. (2002). El trabajo de campo como estrategia metodológica para la enseñanza de las Ciencias de la Tierra. Boletín Multidisciplinario, 12(1). Fundación CENAMEC. Caracas.

Santiago, J. (1998). Las concepciones de los educadores sobre la geografía y su enseñanza desde el trabajo cotidiano. ULA. Departamento de Pedagogía. Revista de Investigación y Postgrado de la UPEL, 13(2), 55-86.

Sauer, C. O. (1956). The Education of a Geographer. Annals of the Association of American Geographers, 46, 287-299. https://doi.org/10.1111/j.1467-8306.1956.tb01510.x

Thomas, I. (2009). Critical Thinking, Transformative Learning, Sustainable Education, and ProblemBased Learning in Universities. Journal of Transformative Education, 7(3), 245-264. https://doi. org/10.1177/1541344610385753

Torrisi-Steel, G. (2009). Pedagogical Perspectives on M-Learning. Encyclopedia of Information Science and Technology. https://doi.org/10.4018/978-1-60566-026-4.ch485

Valdivielso, J., \& Moranta, J. (2019). The social construction of the tourism degrowth discourse in the Balearic Islands. Journal of Sustainable Tourism, 27(12), 1876-1892, https://doi.org/10.1080/0966958 2.2019.1660670

Walker, B., Holling, C.S., Carpenter, S.R., \& Kinzig, A. (2004). Resilience, adaptability and transformability in social-ecological systems. Ecology and Society, 9(2), 5. https://doi.org/10.5751/ES-00650-090205

Wark, M. (2015). Molecular red: theory for the Anthropocene. London: Verso.

Wilding, N. (2011). Exploring community resilience in times of rapid change. Dunfermline: Carnegie UK Trust.

Yrigoy, I. (2014). The production of tourist spaces as a spatial fix. Tourism Geographies, 16(4), 636-652. https://doi.org/10.1080/14616688.2014.915876

Yrigoy, I. (2015). La urbanización turística como "solución espacial”. Agentes, planeamiento y propiedad en la Playa de Palma y Magaluf (Mallorca). PhD Thesis in Geography, Geography Department, University of the Balearic Islands. Retrieved from https://dspace.uib.es/xmlui/handle/11201/149079

Yrigoy, I., Artigues, A. A., \& Blázquez-Salom, M. (2013). El papel del Estado en la renovación urbanoturística de espacios turísticos. El caso de la Playa de Palma, Mallorca, España. Revista Bitácora Urbano Territorial, 22(1), 141-151.

Yrigoy, I. Artigues, A. A., \& Blázquez-Salom, M. (2015). Crisis y planificación territorial turística neoliberal en las Islas Baleares. Investigaciones Turísticas, 9, 24-49. http://dx.doi.org/10.14198/INTURI2015.9.02. 